Article

\title{
Social Impact Assessment of Rebuilding an Urban Neighborhood: A Case Study of a Demolition and Reconstruction Project in Petah Tikva, Israel
}

\author{
Tamar Trop \\ Department of Natural Resources \& Environmental Management, Faculty of Management, University of Haifa, \\ 199 Aba Khoushy Ave. Mount Carmel, Haifa 3498838, Israel; tammy20@015.net.il; Tel.: +972-5-2484-4374
}

Received: 1 May 2017; Accepted: 19 June 2017; Published: 21 June 2017

\begin{abstract}
The rebuilding of deteriorating residential areas is being replicated rapidly throughout Israeli cities despite limited assessment of the social consequences. This paper presents the findings of a social impact assessment (SIA) applied to a demolition and reconstruction case study carried out in a low-income neighborhood in Petah Tikva. The project represents a typical example of developer-led removal of low-rise, mixed tenure housing replaced by privately owned high-rise housing. A mixed-methods approach was used to explore the actual and potential social implications from different points of view held by the various public and private actors in the project. The research was based on the analysis of official documents, field observations, and semi-structured interviews with key stakeholders involved in the rebuilding process, and with affected community representatives. The case study was analyzed with regard to three components: the public engagement process, financial well-being, and community cohesion and stability. The assessment revealed insufficient public and municipal involvement, the displacement of the majority of low-income households, disregard for the provision of community infrastructure, and the weakening of community stability. The paper suggests various ways to improve the outcomes of the project for all the affected parties, and argues that incorporating the SIA mechanism in this particular form of urban renewal might improve strategic decision-making and promote urban sustainability.
\end{abstract}

Keywords: urban sustainability; urban regeneration; urban renewal; rebuilding; housing demolition; housing reconstruction; housing policy

\section{Introduction}

In all of Israel's largest cities, inner-city revitalization and housing rebuilding associated with urban renewal has proceeded swiftly throughout the 1990s and the 2000s. Subsequently, these cities are currently undergoing major changes in character and structure. With a view to the overall goal of urban sustainability, the growing scope of these transformation processes raises multi-dimensional questions that must be incorporated into the planning process. In most cases, environmental and transportation concerns were taken into account, but the social consequences of urban renewal projects at large, and particularly the impacts associated with the demolition of derelict residential areas and the reconstruction of high-rise housing, have not been widely studied. Therefore, decision making in the Israeli context has not been sufficiently informed.

Social impact assessment (SIA) can be used for both ex-ante evaluation of the merits of these planned interventions, as well as ex-post evaluation of the activities undertaken. Although the specialized literature states that SIA must be performed before projects become operational [1,2], other scholars understand ex-post assessment as a section of SIA to be carried out during the monitoring phase [3-6]. In fact, much of the existing knowledge about social impacts is based on social 'follow ups' and ex-post facto studies of existing projects and policies. In accordance with this second view, 
this paper presents the results of an ex-post evaluation, which demonstrates how conducting SIA before launching a demolition and high-rise reconstruction project could have alleviated potential undesirable social impacts on affected communities. Initially, this paper briefly reviews the characteristics of housing renewal and high-rise projects to clarify the need to perform a specific SIA for each project.

\subsection{Housing Renewal and High-Rise Buildings}

Over the past two decades, urban renewal has become a major means of increasing the efficiency of land production in many cities around the globe. The key driving forces behind this course of action are the prevention of urban sprawl, the avoidance of new soil consumption, the increase of urban density, and the improvement of neighborhood quality [7-10]. Cities are encouraged to improve their built up, degraded, or underused parts, rather than to expand.

Since the 1970s, many public projects of urban renewal have been undertaken all over the world, and their results have been the subject of much criticism [11-14]. Urban renewal varies in context and form, but each case represents an important opportunity to ensure urban sustainability through the simultaneous integration of sociocultural, economic, and environmental considerations. Several urban renewal projects have been implemented with community involvement, while others have considered eminent domain to achieve results [15]. This course of action may well continue, but, for the demolition and rebuilding of large areas of decaying housing, public funds are usually unavailable and private efforts are needed. One of the major problems of private renewal of deteriorating residential areas is the assembly of a site sufficiently large to be economic. Urban renewal over the past generation has encountered this problem, in part, through use of the governmental unit's power of eminent domain to acquire a substantial site, which is then sold to private developers [16]. To obtain the power of eminent domain, a private developer might be required to fulfill various conditions, including the assessment of social impacts. Thus far, however, this requirement has not been incorporated into the Israeli planning process.

The characteristics of projects involving the demolition and reconstruction of derelict residential areas differ significantly from those of general construction projects, especially in terms of their high degree of complexity and uncertainty. The renewal of old residential neighborhoods constitutes a major social stake. Not only does it reorient people's primary living conditions, but it also affects how people of different backgrounds and resources are distributed in spatial terms, raising the problem of segregation [17]. Due to its short-term nature, the social consequences of the demolition and reconstruction of housing within a specific area, over a short period of time, and often on a massive scale, are potentially more acute and therefore more visible than in other housing renewal contexts. For instance, an overview of housing interventions in regeneration programs in the UK concluded that one of the biggest challenges facing policy and practice was that 'demolition can prove a distressing experience and the process needs intensive management and community support to minimize disruption' [18] (p. 30).

The communities themselves are often divided in their views regarding the removal of low-rise, usually mixed tenure, housing, and its replacement with mid- and high-rise, privately owned housing. Opposition is usually expressed by individuals or groups of local people, who fear the break-up of their community and disruption of peoples' social support networks through a demolition and redevelopment program $[19,20]$. In addition, a more critical opposition exists to what some see as the privatization of social housing and the instigation of what has been termed 'state-led gentrification', wherein physical renewal is seen as a route to the social transformation of areas [21].

In relation to high-rise living, researchers hold contradictory views. A brief review of the large body of research performed in this area shows that, notwithstanding some examples of studies identifying positive effects of high-rise living [22-24], the majority of research in this area has sought to identify and explain its negative health and social impacts [20]. The potentially harmful effects of high-rise living can be considered in five categories: (a) crime, vandalism, and informal social control, with several studies having identified building height as one of the most influential features for the 
prevalence of 'social malaise' [25,26]; (b) mental health effects, wherein the evidence overall shows that people living in high-rise flats have more mental health problems [27-29]; (c) social effects, wherein several studies have reported that high-rise dwellers have a lower sense of community, less familiarity with their neighbors, and lower levels of social support than other people [28,30,31]; (d) impacts on families and children, wherein high-rise living is generally viewed as inimical to families, mainly as a result of inadequate neighborhood facilities, safety concerns, and the difficulties of supervision at a distance [32,33]; and (e) physical health effects, which are associated mainly with the risk of fatal fires and the 'sick building syndrome', a range of diseases and symptoms such as eye infections, respiratory problems, and headaches [34].

To address the question of social stakes, the analysis of these renewal projects should therefore be based on a structured assessment tool for identifying, monitoring, and managing social impacts. This course of action is followed in this paper by focusing on one specific Israeli housing demolition and reconstruction project, which represents many similar projects currently being undertaken or planned in Israel.

\subsection{Social Impact Assessment}

SIA refers to the processes of analyzing, monitoring, and managing the intended and unintended social consequences, both positive and negative, of planned interventions (policies, programs, plans, projects) and any social change processes invoked by those interventions [35-38]. Its primary purposes are to alleviate developmental impacts, understand different stakeholders' perceptions, and bring about a more sustainable and equitable biophysical and human environment. Through this risk-assessment method, urban planners can develop comprehensive qualitative and quantitative indicators to estimate, predict, and report any social changes associated with a wide range of planned interventions [36,37,39].

SIA includes the effective engagement of interested and affected parties in participatory processes. To engage stakeholders in the analysis of social impacts, Lockie [40] suggested that SIA practitioners should consider conflicting interests and values among stakeholders in the development project. Furthermore, Vanclay et al. [37] explained that practitioners can (a) provide a better understanding of the local values and experiences of different stakeholder groups; (b) help affected residents understand the planned intervention and its implications; and (c) invite affected residents to enhance the design of the development projects.

Although SIA is commonly used as an impact prediction mechanism to consider the social impacts in advance of a permitting or licensing decision, equally important is the role of SIA in contributing to the ongoing management of social issues throughout the whole project development cycle from conception to post-closure $[37,38,41,42]$.

SIA can be undertaken in different contexts and for different purposes, and can refer to different types of social impacts, creating difficulties in its definition or evaluation. The nature of an SIA performed on behalf of an investor, a company, or a multinational corporation as part of its internal procedures, may differ greatly from an SIA undertaken by a consultant in compliance with regulatory or funding agency requirements, or from an SIA undertaken by a development agency interested in ensuring best value for its country's development assistance. These, in turn, may differ greatly from an SIA undertaken by staff or students at a local university on behalf of the local community, or from an SIA performed by a non-governmental organization, or by the local community itself. Each of these applications of SIA is worthwhile, and none should pretend to be the definitive statement. Therefore, an evaluation of an SIA needs to consider its intended purpose.

SIA first emerged in the United States in the 1970s and since then has been progressively introduced in many countries around the world [43-45]. In Israel, however, notwithstanding the well-established mechanism for environmental impact assessment, a social assessment requirement regarding development projects is still lacking. At present, no specific governmental, public, or private mechanism is responsible for conducting SIA and for providing opinions to the planning board. 
In light of the absence of a formal requirement for conducting SIA in Israel, as well as the lack of specific studies on the social effects of housing demolition and rebuilding projects in Israel, and considering the limited public availability of SIA reports for similar case studies carried out in other counties, this article seeks to demonstrate how the use of SIA might contribute to alleviating the undesirable social impacts of these complex projects. This, in turn, might assist promoters and managers of similar projects to optimize the allocation of limited resources and advance urban sustainability.

\section{Methods}

SIA is a community of practice with its own paradigm of theories, methods, case histories, expected understandings, and values [37,42,46,47]. Furthermore, the methodology of SIA can be undertaken on behalf of a wide range of actors and not merely within a regulatory framework. This paradigm is embodied and articulated in the International Principles for Social Impact Assessment [36,37]. The reflections of international principles pertaining to development provide insights for this study to evaluate the nature of the social impacts, how the demolition and reconstruction of a housing project dealt with affected residents' needs, and whether conducting an ex-post SIA could have provided more effective planning outputs. For development-induced displacement, a strong international understanding of the principles that SIA practitioners should consider is emerging and includes the following main principles: (1) avoid or minimize displacement by exploring alternative project designs; (2) avoid forced eviction by using negotiated agreements; (3) anticipate adverse social, economic, and human rights impacts; and (4) provide appropriate disclosure of information and allow for the informed participation of those affected [37] (p. 25). It is noteworthy that in the absence of defined SIA procedures, methods, and report formats in Israel, there is room for individual researchers to interpret the principles and guidelines of SIA according to their values and judgment.

\subsection{Case Study: Yosefsberg Demolition and Reconstruction Project in Petah Tikva}

In recent years, tall buildings and high-rise apartment blocks have featured prominently in redevelopment projects in the city of Petah Tikva in central Israel. The SIA analysis relates to two adjacent demolition and reconstruction projects, which occupy a total area of 13,500 square meters in the Ahdut neighborhood in the south-eastern part of the city (Figure 1). The first project (Local Planning Scheme No. PT/1238/16) was initiated in 1998, approved in 2011, and is currently in an advanced stage of construction, with one out of two buildings already built and inhabited (Figure 2), whereas the second project (Local Planning Scheme No. 410-0118299) was initiated in 2015 and was recently put on hold at the planning stage. The neighborhood is characterized by low socioeconomic status, with the local populace frequently suffering from considerable social and economic precariousness. Nonetheless, its close proximity to main roads and to sought-after neighborhoods has drawn the attention of developers.

Due to the proximity of the projects in terms of space and time, the similarity of their characteristics, and their location in the same local community, the study refers to them as one project divided into two sections. The community in the adjacent projects consisted of six run-down four-story tenement blocks, built in the 1950s and 1960s, with a total of 146 relatively small and low-cost dwellings. About $60 \%$ of the units were occupied by low-income renters, another $10 \%$ by inhabitants of public housing (Amidar and Heled companies), and only $30 \%$ by owners. In other words, most of the dwellings were occupied by vulnerable households with multiple social needs. Consequently, the projects' initiators and developers were faced with issues such as disadvantaged social groups, deteriorating public fabric, and declining environmental quality. Nevertheless, the redevelopment projects focused mainly on improving the area's attractiveness to new residents by tearing down the deteriorating buildings and constructing four 25-35-story high-rise buildings, with a total of 630 relatively large and expensive 
dwellings. Additionally, during the planning and construction processes, there was a lack of formal or informal evaluation to consider the projects' social impacts.

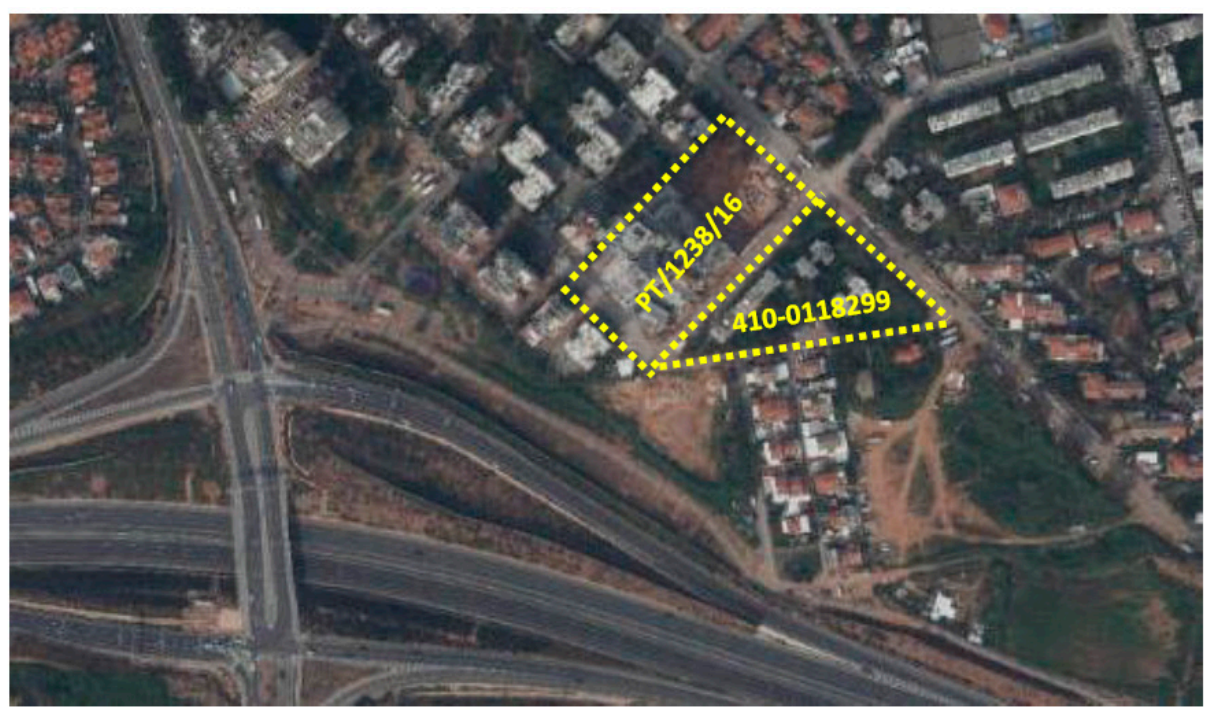

Figure 1. The study area.

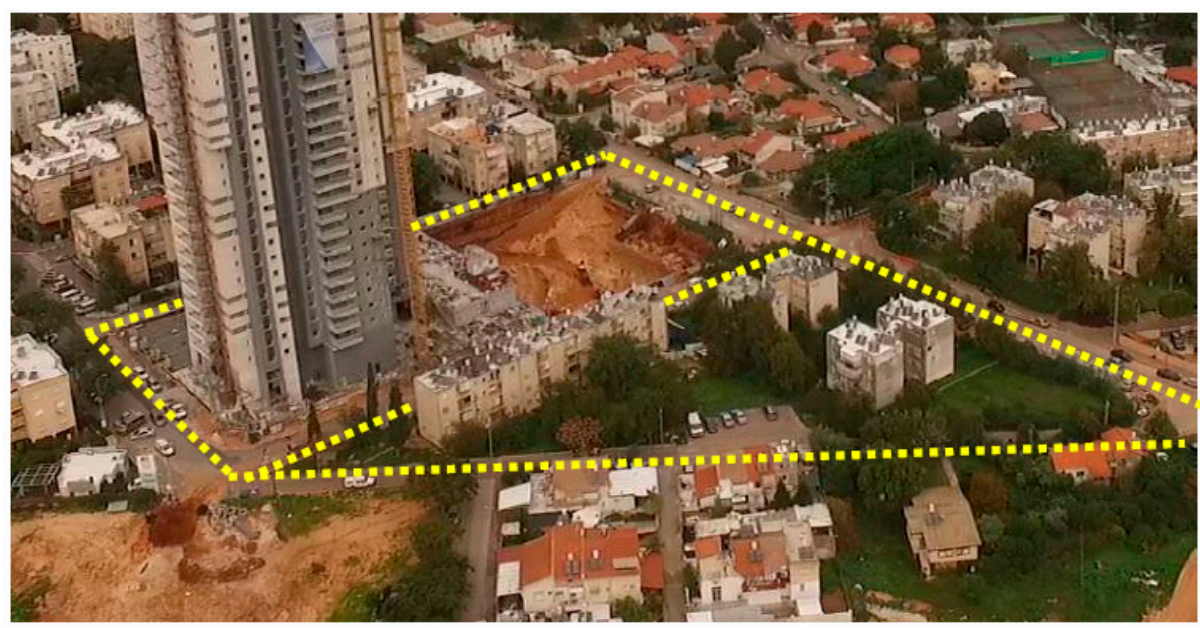

Figure 2. The first completed building (Local Planning Scheme No. PT/1238/16).

Although the Ministry of Construction and Housing defined the area for these projects as fit for demolition and reconstruction, no renewal policy or program existed for the inner city. As a result, the planning and implementation processes were developer-led with very limited municipal and public engagement.

\subsection{Data Collection Methods}

The SIA referred to the project's current stage, which includes one section that is already partially built and inhabited, and another section that has not yet been approved. An ex-post SIA can be performed for the first section to assess some of the actual social impacts, and an ex-ante SIA for the second section can assess the potential impacts. Thus, this case study provides an opportunity to examine impacts during various stages of the project. However, due to the similarity of the project's sections and their proximity in time and space, much of the ex-ante SIA could be based on the findings from the ex-post SIA. Therefore, the author refers to this study as an ex-post SIA. 
The fieldwork for the study was carried out in mid-2016. A mixed-methods research combined demographic, social and economic data, field observations, archival data, and interview data, to establish a picture of the local revealed and perceived social impacts of the project under study.

For the purpose of the study, planning documents relevant for the demolition and reconstruction project were critically analyzed. Semi-structured face-to-face interviews with key stakeholders involved in the planning process and with local affected community representatives were then conducted. Stakeholders were selected for their involvement and influential roles in this project, and community members were selected for their potential to be affected by the project. The main goals of the interviews were to understand the needs, interests, and values of the various actors involved in the demolition and reconstruction project; to reveal if and how social concerns were integrated within the planning and implementation stages; to determine the actual direct and indirect influences of the project; and to expose its perceived impacts.

The author adjusted the set of prepared questions to the subject's position and expertise. Interviewees included the city mayor; heads of the city's Strategic Planning Department and the Welfare Department; representatives from the Ministry of Construction and Housing, the planning agencies (Local and Regional Planning Committees), public housing companies, project directors, civil activists, tenants of old buildings set for demolition (renters, owners, public housing inhabitants), neighboring residents, and newcomers moving in. Another stakeholder group, which was impossible to identify and interview, but nevertheless was considered in the assessment, is the future high-rise occupants. The interviews were carried out by the author, with the assistance of three graduate students in urban planning, who had gained substantial experience in the field.

The author supplemented the interviews with a review of the available official documents, including plans, protocols from the local and regional planning committees, and policy documents. Descriptive demographic and property data were supported by informal observations of neighborhood conditions in and around the project area.

\subsection{The Analysis Process}

The assessment of social impacts followed the International Association for Impact Assessment (IAIA) guidance of assessing and managing the social impacts of projects [37] and was conducted in six main phases, as follows:

(a) Gaining understanding of the project, including the various stages in its lifecycle (as listed along the Y-axis in Table 1).

(b) Identifying the preliminary 'social area of influence' of the project and the potential impacted and beneficiary communities and stakeholders at the various planning and implementation phases (as listed along the $\mathrm{X}$-axis in Table 1).

(c) Understanding the socioeconomic backgrounds of the affected residents and the roles of all affected parties involved in or associated with the project.

(d) Assessing the differing needs, interests, values, and aspirations of the various actors.

(e) Determining the nature (none, positive, or negative, as presented in Table 1) of the actors' potential impact according to various planning and implementation phases and assessing the relative influence power of each of the actors (on a scale of 1 to 4 , as presented in Table 1). This implies the likelihood of their concerns being addressed.

(f) Predicting, analyzing, and assessing the impact pathways. For this purpose, a set of social parameters for impact assessment of the project was established based on the literature review and document analysis, and was finally determined through the interview process, relying on the inputs of stakeholders and affected residents (as listed along the X-axis in Tables 2 and 3). The analysis concerns the nature (positive or negative) and the character of each social impact from the affected stakeholder's point of view. In so doing, the study does not purport to be a systematic evaluation of all relevant impacts, but is an exploratory investigation into real and 
perceived local circumstances in lieu of longitudinal data, which the author acknowledged would be valuable.

(g) Suggesting means to enhance the desirable impacts and alleviate the adverse impacts on affected communities (as presented in Tables 2 and 3 in the next section).

Table 1. Evaluation of the actors' potential impact on the planning and implementation process.

\begin{tabular}{|c|c|c|c|c|c|c|c|c|c|c|c|c|c|c|c|c|}
\hline 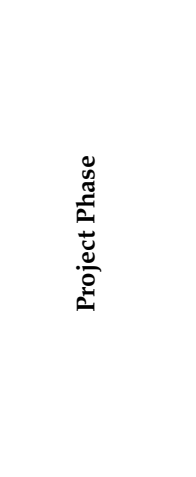 & : & 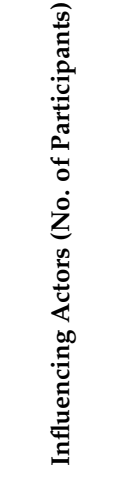 & 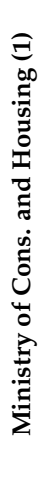 & 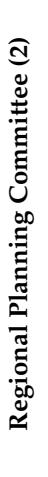 & 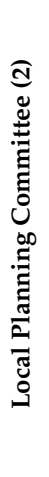 & 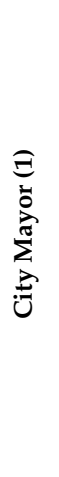 & 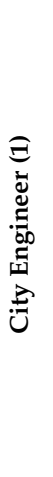 & 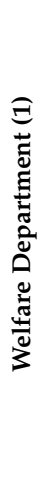 & 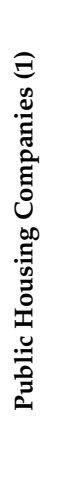 & 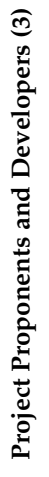 & 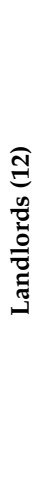 & 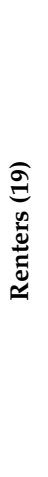 & 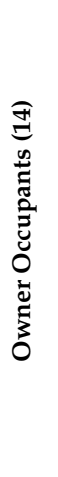 & 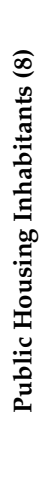 & 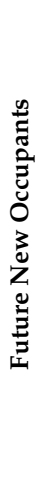 & 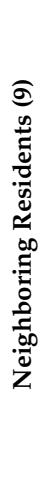 \\
\hline \multirow{6}{*}{$\begin{array}{c}\text { Project } \\
\text { Formulation }\end{array}$} & \multirow[b]{2}{*}{ Site Identification } & Impact & + & & + & + & + & & & + & & & & & & \\
\hline & & $\begin{array}{l}\text { Influence } \\
\text { Power }\end{array}$ & 4 & & 2 & 2 & 2 & & & 4 & & & & & & \\
\hline & \multirow[b]{2}{*}{ Feasibility Check } & Impact & + & & + & & + & & + & + & + & - & + & - & & - \\
\hline & & $\begin{array}{c}\text { Influence } \\
\text { Power }\end{array}$ & 2 & & 4 & & 4 & & 4 & 4 & 4 & 1 & 4 & 2 & & 3 \\
\hline & \multirow{2}{*}{$\begin{array}{c}\text { Obtaining } \\
\text { Owner's } \\
\text { Agreement }\end{array}$} & Impact & & & & & & & + & + & + & - & + & - & & \\
\hline & & $\begin{array}{l}\text { Influence } \\
\text { Power }\end{array}$ & & & & & & & 4 & 4 & 4 & 1 & 4 & 2 & & \\
\hline \multirow{4}{*}{ Planning } & \multirow[b]{2}{*}{ Plan Preparation } & Impact & & + & + & & + & & & + & + & & + & & & \\
\hline & & $\begin{array}{l}\text { Influence } \\
\text { Power }\end{array}$ & & 4 & 2 & & 2 & & & 4 & 4 & & 4 & & & \\
\hline & \multirow[b]{2}{*}{ Plan Approval } & Impact & & + & + & + & + & & & + & & & & & & - \\
\hline & & $\begin{array}{l}\text { Influence } \\
\text { Power }\end{array}$ & & 4 & 4 & 2 & 4 & & & 4 & & & & & & 3 \\
\hline \multirow{4}{*}{ Licensing } & \multirow[b]{2}{*}{$\begin{array}{l}\text { Signing Contracts } \\
\text { with Owners }\end{array}$} & Impact & & & & & & & + & + & + & - & + & - & & \\
\hline & & $\begin{array}{l}\text { Influence } \\
\text { Power }\end{array}$ & & & & & & & 4 & 4 & 4 & 2 & 4 & 3 & & \\
\hline & \multirow{2}{*}{$\begin{array}{c}\text { Obtaining } \\
\text { Building Permit }\end{array}$} & Impact & & & + & + & + & & & + & + & - & + & - & & \\
\hline & & $\begin{array}{l}\text { Influence } \\
\text { Power }\end{array}$ & & & 4 & 2 & 4 & & & 4 & 4 & 1 & 4 & 1 & & \\
\hline \multirow{6}{*}{ Implementation } & \multirow[b]{2}{*}{ Tenant Eviction } & Impact & & & & & & + & + & + & + & - & + & - & & \\
\hline & & $\begin{array}{c}\text { Influence } \\
\text { Power }\end{array}$ & & & & & & 3 & 4 & 4 & 4 & 2 & 4 & 2 & & \\
\hline & \multirow[b]{2}{*}{ Demolition } & Impact & & & & & & & + & & & & & & & - \\
\hline & & $\begin{array}{l}\text { Influence } \\
\text { Power }\end{array}$ & & & & & & & 4 & & & & & & & 2 \\
\hline & \multirow[b]{2}{*}{ Construction } & Impact & & & & & & & + & & & & & & & - \\
\hline & & $\begin{array}{l}\text { Influence } \\
\text { Power }\end{array}$ & & & & & & & 4 & & & & & & & 2 \\
\hline \multirow{4}{*}{ Operation } & \multirow[b]{2}{*}{$\begin{array}{l}\text { Building } \\
\text { inhabitation }\end{array}$} & Impact & & & & & & & & & + & & + & & + & \\
\hline & & $\begin{array}{c}\text { Influence } \\
\text { Power }\end{array}$ & & & & & & & & & 4 & & 4 & & 4 & \\
\hline & \multirow{2}{*}{$\begin{array}{l}\text { Building } \\
\text { operation }\end{array}$} & Impact & & & & & & & & & & & & & & \\
\hline & & $\begin{array}{l}\text { Influence } \\
\text { Power }\end{array}$ & & & & & & & & & & & & & & \\
\hline
\end{tabular}

(+) Positive influence; (-) Negative influence; ( ) Not relevant; (1) Low; (2) Medium; (3); High; (4) Very High. 
Essentially, urban demolition and reconstruction projects involve various stakeholders or stakeholder groups with different interests and entail a high degree of interaction among them. As a result, these projects have high uncertainty and complexity factors, which might affect successful completion.

\section{Findings and Implications}

\subsection{The Planning and Development Process}

According to the interviews and the documents, the project was privately initiated. As stated by the representatives of the planning agencies and the urban designers who spearheaded the project, the focus was on the built environment. The main vision was to enhance the quality of the neighborhood, to modify its image, and to improve its attractiveness to middle-class households. This population change also relies on a shift in the balance between housing units of different statuses within this area. Accordingly, demolition and reconstruction must necessarily lead to a decrease in the proportion of social housing and private renting and an increase in property ownership.

Therefore, the renewal project was concerned mainly with property development, and, at that time, social sustainability was not specifically identified as a priority. The interviewed social worker pointed out that no assessment procedure of social impacts was performed before and during the planning process, and no ongoing assessment was conducted during and after the implementation of the first section of the project (no. PT/1238/16).

The findings evidently show that no clear mechanisms were incorporated early on in the process to prevent the displacement of low-income groups. This means, for instance, that the interests of the renters, who occupied about $60 \%$ of the units, were not considered, and they had little influence on the planning process. Consequently, in the first section, the renters had to be relocated out of the project area. In addition, the plans were launched without holistically evaluating the interrelationships between the project area and its surrounding neighborhoods. Moreover, according to the interviews, adequate community services in the neighborhood are still greatly lacking.

The growing awareness of the lack of comprehensive land-use planning of the wider area and the disregard by the developers for the provision of suitable community infrastructure for both sections of the project, has led the regional planning committee to stall the second project's approval processes until the municipality and the local planning committee submit a sound policy paper for further redevelopment of the wider area.

The interviewees indicated also that the public engagement process has included only the key stakeholders, i.e., the owners and public housing companies, whereas the underprivileged groups (mainly renters and public housing inhabitants) had limited power and were not sufficiently organized to have an impact on urban planning decisions. Moreover, even the key stakeholders were not heavily involved in the decision-making process during the preparation of the planning schemes.

\subsection{Project-Related Social Impacts}

As a practical policy, demolition and reconstruction affects the lives of the local community and of the surrounding residents in many ways, some of which will be presented here. Other effects will not be explored or will be referred to only for background information, such as the consequences of the project for households' economic resources or the project's impact on residents' careers. Instead, the SIA focus will be on three key categories of social impacts that are central to demolition and reconstruction consequences: the public engagement process, the impacts on financial well-being, and the impacts on community cohesion and stability (including relocation complications). The analysis concerns the nature (positive or negative) and the character of each social impact from the affected party's point of view. To address these impacts, the SIA suggests particular measures to ameliorate the project's outcomes. The key findings and suggested measures are summarized in Tables 2 and 3. 
Table 2. Desirable social impacts and suggested means for their enhancement.

\begin{tabular}{|c|c|c|c|}
\hline Social Issue & Affected Group & Impact & Suggested Means to Enhance the Impact \\
\hline \multirow{6}{*}{$\begin{array}{l}\text { Public } \\
\text { Engagement } \\
\text { Process }\end{array}$} & Owner Occupants & $\begin{array}{l}\text { Involvement during project formulation phase, } \\
\text { as their agreement was a prerequisite for planning }\end{array}$ & $\begin{array}{l}\text { Involving owners in the full planning process in order to adequately } \\
\text { address their various needs regarding dwelling mix and provision of } \\
\text { neighborhood public spaces, public services, and transportation }\end{array}$ \\
\hline & Landlords & $\begin{array}{l}\text { Involvement during project formulation phase, } \\
\text { as their agreement was a prerequisite for planning }\end{array}$ & $\begin{array}{l}\text { Involving landlords in the full planning process in order to adequately } \\
\text { address their preferences and concerns regarding rental potential }\end{array}$ \\
\hline & Public Housing Inhabitants & - & \\
\hline & Renters & - & \\
\hline & Public Housing Companies & $\begin{array}{l}\text { Involvement during project formulation phase, } \\
\text { as their agreement was a prerequisite for planning }\end{array}$ & $\begin{array}{l}\text { Involving companies in the planning process in order to adequately } \\
\text { address their preferences and concerns regarding dwelling mix and } \\
\text { provision of community infrastructure }\end{array}$ \\
\hline & $\begin{array}{l}\text { Neighboring Residents and } \\
\text { Wider Community }\end{array}$ & - & - \\
\hline \multirow{4}{*}{$\begin{array}{l}\text { Financial } \\
\text { well-being }\end{array}$} & Owner Occupants & $\begin{array}{l}\text { Provision of new, larger, and more expensive dwellings; } \\
\text { enhanced neighborhood quality; } \\
\text { receiving rental fees for alternative accommodation during } \\
\text { construction without providing proof of actual renting }\end{array}$ & $\begin{array}{l}\text { Involving owners in the detailed planning process in order to } \\
\text { maximize their capital gain (not at the expense of developers' profit) }\end{array}$ \\
\hline & Landlords & $\begin{array}{l}\text { Provision of new, larger, and more expensive dwellings; } \\
\text { receiving higher rental fees; } \\
\text { fewer maintenance worries; } \\
\text { receiving rental fees during construction with no tenant } \\
\text { management issues and maintenance worries }\end{array}$ & $\begin{array}{l}\text { Involving owners in the detailed planning process in order to } \\
\text { maximize their capital gain (not at the expense of developers' profit) }\end{array}$ \\
\hline & Public Housing Inhabitants & $\begin{array}{l}\text { Provision of new and larger dwellings; } \\
\text { receiving rental fees for renting alternative accommodation } \\
\text { during construction; } \\
\text { fewer maintenance worries }\end{array}$ & $\begin{array}{l}\text { Involving public housing inhabitants in the planning process to better } \\
\text { meet their specific needs }\end{array}$ \\
\hline & City/Municipality & $\begin{array}{l}\text { Economic advantages due to increased urban density; } \\
\text { privately-funded enhanced neighborhood quality; } \\
\text { modified neighborhood image; } \\
\text { a trigger to additional privately initiated renewal of } \\
\text { deteriorating neighborhoods; } \\
\text { increased city property tax revenues; } \\
\text { decreased socioeconomic spatial segregation; } \\
\text { increased socioeconomic status of the city; } \\
\text { local economic activation }\end{array}$ & $\begin{array}{l}\text { Holistically evaluating the interrelationships between the } \\
\text { project area and its surrounding neighborhoods and conducting } \\
\text { long-term planning }\end{array}$ \\
\hline
\end{tabular}


Table 2. Cont

\begin{tabular}{|c|c|c|c|}
\hline Social Issue & Affected Group & Impact & Suggested Means to Enhance the Impact \\
\hline \multirow{4}{*}{$\begin{array}{l}\text { Financial } \\
\text { well-being }\end{array}$} & $\begin{array}{l}\text { Project Proponents and } \\
\text { Developers }\end{array}$ & Capital gain & $\begin{array}{l}\text { Provision of new or upgraded community infrastructure can boost the } \\
\text { amenity of the project and might make the project more attractive to } \\
\text { residents or for further development }\end{array}$ \\
\hline & Public Housing Companies & $\begin{array}{l}\text { Enhanced public housing stock quality and value; } \\
\text { receiving rental fees during construction for vacant dwellings } \\
\text { without maintenance worries; } \\
\text { fewer repairs and maintenance costs of new social } \\
\text { housing dwellings }\end{array}$ & $\begin{array}{l}\text { Involving the companies in the detailed planning process in order to } \\
\text { maximize affordable public housing stock }\end{array}$ \\
\hline & New and Future Occupants & $\begin{array}{l}\text { More housing options; } \\
\text { high quality dwellings at relatively affordable prices } \\
\text { (compared to nearby sought-after neighborhoods); } \\
\text { dwelling values are likely to rise quickly in the short-term }\end{array}$ & \\
\hline & $\begin{array}{l}\text { Neighboring Residents and } \\
\text { Wider Community }\end{array}$ & $\begin{array}{l}\text { For owners: increased property value and rental fees; } \\
\text { for all: improved neighborhood image }\end{array}$ & \\
\hline \multirow{4}{*}{$\begin{array}{l}\text { Community } \\
\text { Cohesion and } \\
\text { Stability }\end{array}$} & City/Municipality & $\begin{array}{l}\text { Transformation of deteriorating public spaces; } \\
\text { treatment of environmental hazards; } \\
\text { enhancement of environmental and social equity as mixing } \\
\text { tenures will automatically bring some level of social mix } \\
\text { enhanced integrated social housing estates, which promote } \\
\text { socially and economically integrated communities; } \\
\text { greater community diversity in terms of age profile, } \\
\text { income levels, employment profile, household size, } \\
\text { and household type }\end{array}$ & \\
\hline & Owner Occupants & $\begin{array}{l}\text { Enhanced neighborhood safety and social interactions } \\
\text { (the more secure people feel in their neighborhoods, the better } \\
\text { the level of social cohesion and neighborhood interaction); } \\
\text { increased usage of commonly shared spaces; } \\
\text { strengthening occupants' sense of place; } \\
\text { increased population density can meet the thresholds for } \\
\text { additional and high quality public services, facilities and } \\
\text { neighborhood retail }\end{array}$ & \\
\hline & Landlords & Attraction of higher income and more reliable tenants & \\
\hline & Public Housing Inhabitants & $\begin{array}{l}\text { Enhanced neighborhood safety; } \\
\text { increased usage of commonly shared spaces; } \\
\text { strengthening occupants' sense of place; } \\
\text { increased social interactions }\end{array}$ & \\
\hline
\end{tabular}


Table 2. Cont

\begin{tabular}{|c|c|c|c|}
\hline Social Issue & Affected Group & Impact & Suggested Means to Enhance the Impact \\
\hline \multirow{3}{*}{$\begin{array}{l}\text { Community } \\
\text { Cohesion and } \\
\text { Stability }\end{array}$} & Renters & - & \\
\hline & New and Future Occupants & $\begin{array}{l}\text { New households residing in the neighborhood usually have } \\
\text { higher incomes and more stable employment situations than } \\
\text { the original occupants; } \\
\text { improved maintenance of commonly shared spaces; } \\
\text { increased neighborhood influence power on local } \\
\text { decision makers }\end{array}$ & \\
\hline & $\begin{array}{l}\text { Neighboring Residents and } \\
\text { Wider Community }\end{array}$ & $\begin{array}{l}\text { Enhanced neighborhood safety; } \\
\text { potential trigger for neighborhood renewal; } \\
\text { increased population density can meet the thresholds for } \\
\text { additional and higher quality community infrastructure }\end{array}$ & \\
\hline
\end{tabular}

Table 3. Social stakes and suggested mitigation measures.

\begin{tabular}{|c|c|c|c|}
\hline Social Issue & Affected Group & Impact & Suggested Mitigation Measures \\
\hline \multirow{6}{*}{$\begin{array}{l}\text { Public } \\
\text { Engagement } \\
\text { Process }\end{array}$} & Owner Occupants & $\begin{array}{l}\text { Insufficient involvement in the full planning process reduced } \\
\text { their ability to maximize profits and to ensure catering for their } \\
\text { specific needs; } \\
\text { insufficient involvement led to lack of sufficient amenities and } \\
\text { public services }\end{array}$ & $\begin{array}{l}\text { Involving owners in the planning process in order to tailor dwelling } \\
\text { characteristics and community infrastructure to their needs; } \\
\text { local decision makers should encourage and assist owners to organize and } \\
\text { exercise their collective power to determine the future design of the } \\
\text { development plan; } \\
\text { conducting consultation and information dissemination about the project }\end{array}$ \\
\hline & Landlords & $\begin{array}{l}\text { Insufficient involvement in the full planning process reduces } \\
\text { their ability to maximize profits }\end{array}$ & $\begin{array}{l}\text { Involving landlords in the planning process in order to adequately address } \\
\text { their preferences and concerns regarding rental potential; } \\
\text { local decision makers should encourage and assist landlords to organize and } \\
\text { exercise their collective power to fulfill their choices }\end{array}$ \\
\hline & Public Housing Inhabitants & Lack of involvement in all project phases & $\begin{array}{l}\text { Involving public housing inhabitants in the planning process in order to } \\
\text { adequately address their needs regarding dwelling characteristics and } \\
\text { community infrastructure; } \\
\text { local decision makers should encourage and assist public housing inhabitants } \\
\text { to organize and exercise their collective power to determine their future } \\
\text { in the project; } \\
\text { conducting consultation and information dissemination about the project }\end{array}$ \\
\hline & Renters & Lack of involvement in all project phases & Engaging renters to understand their needs \\
\hline & Public Housing Companies & $\begin{array}{l}\text { Insufficient involvement in the full planning process reduces } \\
\text { their ability to maximize affordable public housing stock }\end{array}$ & Involving the companies in the detailed planning process \\
\hline & $\begin{array}{l}\text { Neighboring Residents and } \\
\text { Wider Community }\end{array}$ & $\begin{array}{l}\text { Limited involvement of the low-income groups in the } \\
\text { planning process }\end{array}$ & $\begin{array}{l}\text { Local decision makers should encourage and assist neighboring residents to } \\
\text { organize and exercise their collective power to be involved in the } \\
\text { planning process }\end{array}$ \\
\hline
\end{tabular}


Table 3. Cont

\begin{tabular}{|c|c|c|c|}
\hline Social Issue & Affected Group & Impact & Suggested Mitigation Measures \\
\hline \multirow{4}{*}{$\begin{array}{l}\text { Financial } \\
\text { Well-Being }\end{array}$} & Owner Occupants & $\begin{array}{l}\text { Limited accommodation options for lone persons and couples } \\
\text { without dependent households; } \\
\text { receiving the bottom, usually cheaper, floor units; } \\
\text { a considerable increase in housing costs, which are likely to } \\
\text { continue rising; } \\
\text { expensive maintenance of new buildings }\end{array}$ & $\begin{array}{l}\text { Involving owners in the detailed planning process in order to maximize their } \\
\text { capital gain (not at the expense of developers' profit); } \\
\text { local decision makers should develop and encourage the development of } \\
\text { innovative housing designs which address diverse needs; } \\
\text { planning controls to enable, encourage, or require a mix of dwelling types }\end{array}$ \\
\hline & Landlords & $\begin{array}{l}\text { Difficulty finding new tenants during planning and licensing } \\
\text { phases (which can take years) }\end{array}$ & Setting terms for adequate compensation in the agreement \\
\hline & Public Housing Inhabitants & $\begin{array}{l}\text { Increased difficulty in finding alternative low-rent dwellings in } \\
\text { the area until the completion of the construction; public and } \\
\text { privately rented dwelling options are particularly limited for } \\
\text { low-income households, and those households might even be } \\
\text { driven out of the city to find more affordable housing; } \\
\text { limited accommodation options for lone persons and couples } \\
\text { without dependent households; } \\
\text { a considerable increase in housing costs, which are likely to } \\
\text { continue rising }\end{array}$ & $\begin{array}{l}\text { Providing grants to assist eligible persons to access or maintain private } \\
\text { rental housing; } \\
\text { providing advice regarding the location of housing opportunities; } \\
\text { offering financial assistance to displaced residents, such as cash contribution } \\
\text { or relocation costs; }\end{array}$ \\
\hline & City/Municipality & $\begin{array}{l}\text { Decrease in affordable housing stock and the disappearance of } \\
\text { a large number of low-cost housing units; } \\
\text { community infrastructure requirements were not taken into } \\
\text { account in the planning }\end{array}$ & $\begin{array}{l}\text { Plan may be approved if the proponent replaces existing affordable housing } \\
\text { with an equivalent supply of affordable housing on the site, or in close } \\
\text { location; } \\
\text { create planning scheme amendments that facilitate affordable housing supply; } \\
\text { develop a clear local policy for demolition and construction projects that } \\
\text { considers the provision of supportive infrastructure to meet the needs and } \\
\text { demographic of the area's population; } \\
\text { controls to protect low-cost housing supply; } \\
\text { planning controls to encourage the provision of affordable housing in } \\
\text { designated areas; } \\
\text { development of bonus systems that offer the prospect of more intense or } \\
\text { higher value development if the proponent is prepared to include affordable } \\
\text { housing in the project; } \\
\text { greater involvement of the municipality in the provision of public housing, } \\
\text { including via partnerships with public housing companies }\end{array}$ \\
\hline
\end{tabular}


Table 3. Cont

\begin{tabular}{|c|c|c|c|}
\hline Social Issue & Affected Group & Impact & Suggested Mitigation Measures \\
\hline \multirow{5}{*}{$\begin{array}{l}\text { Financial } \\
\text { Well-Being }\end{array}$} & $\begin{array}{l}\text { Project Proponents } \\
\text { and Developers }\end{array}$ & $\begin{array}{l}\text { The second section of the project was stalled at the planning } \\
\text { stage until the municipality prepares a comprehensive policy } \\
\text { for further redevelopment of the wider area }\end{array}$ & $\begin{array}{l}\text { Including community infrastructure needs in demolition and } \\
\text { reconstruction plans }\end{array}$ \\
\hline & Public Housing Companies & $\begin{array}{l}\text { Increased pressure on the social housing system due to } \\
\text { increased housing costs within the private housing market } \\
\text { stock of affordable housing }\end{array}$ & $\begin{array}{l}\text { Plan may be approved if the proponent replaces existing public housing with } \\
\text { an equivalent supply of affordable public housing on the site or } \\
\text { in close location }\end{array}$ \\
\hline & Renters & $\begin{array}{l}\text { Displacement of lower income households; } \\
\text { increased difficulty in finding alternative low-rent dwellings in } \\
\text { the area as privately rented dwelling options are particularly } \\
\text { limited for low-income households and those households } \\
\text { might even be driven out of the city to find more } \\
\text { affordable housing; } \\
\text { the displacement of lower income households might affect } \\
\text { their ability to participate in the workforce }\end{array}$ & $\begin{array}{l}\text { Providing funding for low-income households in private rental } \\
\text { accommodation; } \\
\text { supporting investment in private rental housing; } \\
\text { providing advice regarding the location of housing opportunities; } \\
\text { advocating government funded rental schemes; } \\
\text { offering financial assistance to displaced residents, such as cash contribution } \\
\text { or relocation costs; } \\
\text { maintaining a proportion of the new development at a fixed rent for } \\
\text { a defined period }\end{array}$ \\
\hline & New and Future Occupants & $\begin{array}{l}\text { Lack of sufficient amenities and public services leads to higher } \\
\text { spending on mobility }\end{array}$ & $\begin{array}{l}\text { Including community infrastructure needs in demolition and } \\
\text { reconstruction projects }\end{array}$ \\
\hline & $\begin{array}{l}\text { Neighboring Residents and } \\
\text { Wider Community }\end{array}$ & $\begin{array}{l}\text { For renters there are increased rental fees; } \\
\text { greater pressure on existing lower income renters to pay higher } \\
\text { rents or move to lower rent locations }\end{array}$ & $\begin{array}{l}\text { Providing advice regarding the location of housing opportunities; } \\
\text { advocating government funded rental schemes }\end{array}$ \\
\hline
\end{tabular}


Table 3. Cont

\begin{tabular}{|c|c|c|c|}
\hline Social Issue & Affected Group & Impact & Suggested Mitigation Measures \\
\hline \multirow{6}{*}{$\begin{array}{l}\text { Community } \\
\text { Cohesion and } \\
\text { Stability }\end{array}$} & Owner Occupants & $\begin{array}{l}\text { Neglect of commonly shared spaces during the planning and } \\
\text { implementation process; } \\
\text { lack of sufficient amenities and public services on estates; } \\
\text { increased polarization due to concentration in the bottom } \\
\text { floor units; } \\
\text { oppressive environment due to number and size of towers; } \\
\text { difficulty in getting to know neighbors and in exercising } \\
\text { informal social control; } \\
\text { social mix between locals and newcomers tends to transform } \\
\text { local forms of coexistence in unpredictable ways; } \\
\text { spatial proximity of households from different social classes, } \\
\text { with different norms and different residential ambitions, might } \\
\text { exacerbate social tensions among inhabitants; } \\
\text { 'enforced communality' in use of facilities; } \\
\text { lower income residents were no longer adequately catered for } \\
\text { as a result of changing communities and service infrastructures }\end{array}$ & $\begin{array}{l}\text { Encouraging owners to take an active role in maintenance of commonly } \\
\text { shared spaces; } \\
\text { ensuring appropriate mix of locals and newcomers' dwellings throughout } \\
\text { each building; } \\
\text { ensuring the provision of the proper services for lower income households; } \\
\text { planning a mix of apartment building types }\end{array}$ \\
\hline & Landlords & $\begin{array}{l}\text { Neglect of commonly shared spaces during planning and } \\
\text { implementation process }\end{array}$ & $\begin{array}{l}\text { Ensuring that renters continue proper maintenance of commonly } \\
\text { shared spaces }\end{array}$ \\
\hline & Public Housing Inhabitants & $\begin{array}{l}\text { Lack of sufficient amenities on estates; } \\
\text { oppressive environment due to number and size of towers; } \\
\text { difficulty in getting to know neighbors and in exercising } \\
\text { informal social control; } \\
\text { less social interaction; } \\
\text { feeling of social exclusion; } \\
\text { lower income residents were no longer adequately catered for } \\
\text { as a result of changing communities and service infrastructures. }\end{array}$ & $\begin{array}{l}\text { Engaging affected residents to understand their needs; } \\
\text { ensuring the provision of the proper services for lower income households; } \\
\text { requiring mixed construction types on redevelopment site. }\end{array}$ \\
\hline & Renters & $\begin{array}{l}\text { Experience the greatest levels of housing stress; } \\
\text { heightened anxiety about the increasingly competitive rental } \\
\text { market; } \\
\text { unwanted moves that take residents away from local social } \\
\text { support and friendship networks and weakens them (in } \\
\text { comparison with other social milieus, working-class social } \\
\text { capital tends to be strongly rooted in a given territory); } \\
\text { unwanted move to other areas, including to unfamiliar and less } \\
\text { accessible locations, might decrease the access to employment } \\
\text { and education opportunities and force higher mobility }\end{array}$ & $\begin{array}{l}\text { Considering alternative project designs or avoiding } \\
\text { project-induced displacement; } \\
\text { ensuring an appropriate supply and mix of affordable housing options; }\end{array}$ \\
\hline & New and Future Occupants & $\begin{array}{l}\text { Low-income households' housing demand does not align with } \\
\text { the new dwelling stock mix }\end{array}$ & Ensuring an appropriate supply and mix of affordable housing options \\
\hline & $\begin{array}{l}\text { Neighboring Residents and } \\
\text { Wider Community }\end{array}$ & $\begin{array}{l}\text { Exposure to nuisances from construction works; } \\
\text { neighborhood polarization }\end{array}$ & 'Demolition controls' to address nuisances during construction \\
\hline
\end{tabular}




\section{Discussion}

To date, no formal requirement exists for conducting SIA in Israel, and studies of the specific social effects of the demolition of derelict low-rise residential areas and the reconstruction of high-rise buildings are lacking. This paper argues that carrying out this particular form of urban renewal is not merely a technical issue or an isolated item. The way it is managed, especially in the context of urban sustainability, must respond to sensitive social issues. The paper demonstrates how conducting an ex-post SIA can highlight the challenges and contradictions between the aims of these initiatives and affected residents' needs, and how the planning and implementation processes could have been better targeted to benefit the existing and future community. By using two adjacent developer-led projects of low-rise demolition and high-rise reconstruction, one of which is already partially inhabited, whereas the other has not yet been approved, in a low-income neighborhood in Petah Tikva as a case study, this paper provides a clear assessment of the major social consequences from the different perspectives of the various public and private actors in the projects (referred to as one project).

Although the SIA study focuses on specific projects within a particular setting, it presents a typical case of inner-city revitalization and housing rebuilding that has proceeded swiftly since the 1990s throughout many cities around the globe, as in all of Israel's largest cities.

Since the case study project focuses mainly on enhancing the area's attractiveness to new residents, the SIA questions its social sustainability for the affected local communities. The study provides a summary of the expected desirable and adverse social impacts from the affected party's point of view, referring to three major components that are central to demolition and reconstruction consequences: the public engagement process, financial well-being, and community cohesion and stability.

The study shows that the renters and public housing inhabitants, who comprise about $70 \%$ of the households, as well as neighboring residents and the wider community, were not involved in the planning and implementation processes, and their actual needs were not considered. Moreover, even the involvement of property owners, i.e., owner-occupants, landlords, and public housing companies, was limited only to the formulation stages of the project and was not used to its full potential to ensure that their housing and community infrastructure needs and concerns are adequately met. The main consequences of this limited involvement are likely to be inadequate characteristics and mix of new dwellings for property owners, and a lack of sufficient amenities and public services on estates for existing and future households. The study also reveals that, whereas financial benefits have been confined to property owners who receive high-quality and larger dwellings, the impacts of accommodation loss and the lack of affordable housing on existing low-income tenants have already resulted in the displacement of poor households and the alteration of the existing social mix, and might also lead to neighborhood polarization. These impacts are closely linked to the fact that the renewal projects are strictly market-driven and were not based on any understanding of the state and the actual needs of the community or of the project's potential impacts on that community. However, it should be noted that the social outcomes of this type of project are context-specific with respect to issues such as culture, socioeconomic status, housing tenure, ownership pattern, and the locality within a city.

Based on these findings, the author suggests various means of improving the outcomes of this type of demolition and reconstruction project for all the affected actors. The recommendations emphasize the proactive role that the municipality should take in the process. This ought to include, inter alia, incorporation into the planning process of an ex-ante SIA, which will be based on the effective involvement of all affected actors; the development of a Social Impact Management Plan to consider various potential impacts, including the dispensation of harms and benefits, mitigation strategies, governance structure, and ongoing monitoring procedures; addressing local housing affordability issues by various strategies; offering financial support to low-income households; ensuring the provision of supportive and adequate community infrastructure; and designing 'demolition controls' to address nuisances during construction. The fact that the second section of the project was stalled at the planning stage by the regional planning committee, only reinforces the approach that, rather 
than perceiving SIA as a cost to the project's initiators, it should be perceived as an appropriate, useful management process that reduces risk and brings benefits to developers and communities.

Finally, as the project under examination is still in progress, the findings presented here must be considered with some caution. It is too early to establish a definitive, overall picture of the project's social consequences, and it will need to be subjected to further empirical research.

Conflicts of Interest: The author declares no conflict of interest.

\section{References}

1. Goldman, L.; Baum, S. Introduction. In Social Impact Analysis: An Applied Anthropology; Goldman, L., Ed.; Berg: New York, NY, USA, 2000; pp. 1-34.

2. Becker, H.A. Social impact assessment. Eur. J. Oper. Res. 2001, 128, 311-321. [CrossRef]

3. Western, J.; Lynch, M. Overview of the social impact assessment process. In Social Impact Analysis: An Applied Anthropology Manual; Goldman, L., Ed.; Berg: Oxford, UK, 2000; pp. 35-62.

4. Ahmadvand, M.; Karami, E.; Zamani, G.; Vanclay, F. Evaluating the use of Social Impact Assessment in the context of agricultural development projects in Iran. Environ. Impact Assess. Rev. 2009, 29, 399-407. [CrossRef]

5. Burdge, R.J. Benefiting from the practice of social impact assessment. Impact Assess. Proj. Apprais. 2012, 21, 225-229. [CrossRef]

6. Aledo, A.; Garcia-Andreu, H.; Pinese, J. Using causal maps to support ex-post assessment of social impacts of dams. Environ. Impact Assess. Rev. 2015, 55, 84-97. [CrossRef]

7. Kleinhans, R.J. Social implications of housing diversification in urban renewal: A review of recent literature. J. Hous. Built Environ. 2004, 19, 367-390. [CrossRef]

8. Couch, C.; Leontidou, L.; Petschel-Held, G. Urban Sprawl in Europe: Landscapes, Land-Use Change and Policy; Blackwell Publishing Ltd.: Oxford, UK, 2007.

9. Hodson, M.; Marvin, S. Can cities shape socio technical transitions and how would we know if they were? Res. Policy 2010, 39, 477-485. [CrossRef]

10. Riera Pérez, M.C.; Rey, E. A multi-criteria approach to compare urban renewal scenarios for an existing neighborhood. Case study in Lausanne (Switzerland). Build. Environ. 2013, 65, 58-70. [CrossRef]

11. Gilbert, P. Social stakes of urban renewal: Recent French housing policy. Build. Res. Inf. 2009, 37, 638-648. [CrossRef]

12. Clawson, M. Suburban Land Conversion in the United States: An Economic and Governmental Process; Resources for The Future Press: New York, NY, USA, 2011.

13. Darchen, S.; Ladouceur, E. Social Sustainability in Urban Regeneration Practice: A Case Study of the Fortitude Valley Renewal Plan in Brisbane. Aust. Plan. 2013. Available online: http://www.tandfonline.com/loi/ rapl20 (accessed on 1 February 2017).

14. Munzer, K.; Shaw, K. Renew Who? Benefits and Beneficiaries of Renew Newcastle. Urban Policy and Research. 2015. Available online: http:/ /www.tandfonline.com/loi/cupr20 (accessed on 1 February 2017).

15. Murgante, B.; Danese, M.; Las Casas, G. Analyzing Neighbourhoods Suitable for Urban Renewal Programs with Autocorrelation Techniques. In Advances in Spatial Planning; Jaroslav, B., Ed.; InTech: Rijeka, Croatia, 2012. Available online: http://www.intechopen.com/books/advances-in-spatial-planning/analyzingneighbourhoods-suitable-for-urban-renewal-programs-with-autocorrelation-techniques (accessed on 1 February 2017).

16. Freedman, A. Sustainable Urban Renewal: The Tel Aviv Dilemma. Sustainability 2014, 6, 2527-2537.

17. Verhage, R. Renewing urban renewal in France, the UK and the Netherlands: An introduction. J. Hous. Built Environ. 2005, 20, 215-227. [CrossRef]

18. Cole, I.; Foden, M.; Robinson, D.; Wilson, I. Interventions in Housing and the Physical Environment in Deprived Neighbourhoods. Evidence from the New Deal for Communities Programme; CLG: London, UK, 2010. 
19. Goetz, E. Desegregation in 3D: Displacement, dispersal and development in American public housing. Hous. Stud. 2010, 25, 137-158. [CrossRef]

20. Kearns, A.; Whitley, E.; Mason, P.; Bond, L. Living the High Life? Residential, social and psychosocial outcomes for high-rise occupants in a deprived context. Hous. Stud. 2012, 27, 97-126. [CrossRef]

21. Slater, T. The eviction of critical perspectives from gentrification research. Int. J. Urban Reg. Res. 2006, 30, 737-757. [CrossRef]

22. Towers, G. Shelter Is Not Enough: Transforming Multi-Storey Housing; The Policy Press: Bristol, UK, 2000.

23. Turok, I. Cities, competition and competitiveness: Identifying new connections. In Changing Cities: Rethinking Urban Competitiveness, Cohesion and Governance; Buck, N., Gordon, I., Harding, A., Turok, I., Eds.; Palgrave Macmillan: Basingstoke, UK, 2005.

24. Doucet, B. Rich Cities with Poor People: Waterfront Regeneration in the Netherlands and Scotland; Netherlands Geographical Studies 391; Geography Faculty, University of Utrecht: Utrecht, The Netherlands, 2010.

25. Coleman, A. Utopia on Trial: Vision and Reality in Planned Housing; Hilary Shipman: London, UK, 1985.

26. Sim, D. British Housing Design; Longman: Harlow, UK, 1993.

27. Evans, G. The built environment and mental health. J. Urban Health 2003, 80, 536-555. [CrossRef] [PubMed]

28. Evans, G.; Wells, N.M.; Moch, A. Housing and mental health: A review of the evidence and a methodological and conceptual critique. J. Soc. Issues 2003, 59, 475-500. [CrossRef]

29. Wener, R.; Carmalt, H. Environmental psychology and sustainability in high-rise structures. Technol. Soc. 2005, 28, 157-167. [CrossRef]

30. Musterd, S.; van Kempen, R. Large Housing Estates in European Cities: Opinions of Residents on Recent Developments; Urban and Regional Research Centre: Utrecht, The Netherlands, 2005.

31. Yuen, B. Squatters no more: Singapore social housing. Urban Dev. 2007, 3, 1-22.

32. Evans, G.; Lercher, P.; Kofler, W. Crowding and children's mental health: The role of house type. J. Environ. Psychol. 2002, 22, 221-232. [CrossRef]

33. Yuen, B.; Yeh, A.; Appold, S.J.; Earl, G.; Ting, J.; Kwee, L.K. High-rise living in Singapore public housing. Urban Stud. 2006, 43, 583-600. [CrossRef]

34. Waldorf, P. Health Hazards from Pigeons, Starlings and English Sparrows; Bell Environmental Services: London, UK, 2006.

35. Becker, H.A.; Vanclay, F. (Eds.) The International Handbook of Social Impact Assessment; Edward Elgar: Cheltenham, UK, 2003.

36. Vanclay, F. International principles for social impact assessment. Impact Assess. Proj. Apprais. 2003, $21,5-11$. [CrossRef]

37. Vanclay, F.; Esteves, A.M. Current issues and trends in social impact assessment. In New Directions in Social Impact Assessment: Conceptual and Methodological Advances; Vanclay, F., Esteves, A.M., Eds.; Edward Elgar: Cheltenham, UK, 2011; pp. 3-19.

38. International Association for Impact Assessment (IAIA). Social Impact Assessment. Available online: http:/ / www.iaia.org/wiki-details.php?ID=23 (accessed on 1 February 2017).

39. Grieco, C. Assessing Social Impact of Social Enterprises: Does One Size Really Fit All? Springer Briefs in Business; Springer: Cham, Switzerland, 2015.

40. Lockie, S. SIA in review: Setting the agenda for impact assessment in the 21st century. Impact Assess. Proj. Apprais. 2001, 19, 277-288. [CrossRef]

41. Vanclay, F.; Esteves, A.M.; Aucamp, I.; Franks, D. Social Impact Assessment: Guidance for Assessing and Managing the Social Impacts of Projects; International Association for Impact Assessment: Fargo, ND, USA, 2015.

42. Esteves, A.M.; Franks, D.; Vanclay, F. Social impact assessment: The state of the art. Impact Assess. Proj. Apprais. 2012, 30, 35-44. [CrossRef]

43. Cooke, B.; Kothari, U. Participation: The New Tyranny? Zed Books: London, UK, 2001.

44. Taylor, C.N.; Bryan, C.H.; Goodrich, C.G. Social Impact Assessment: Theory, Process and Techniques; Social Ecology Press: Middleton, WI, USA, 2004.

45. Ng, M.K.; Hui, D.L.H. Practice report: Sustainability impact assessment in Hong Kong and the Pearl River Delta: Both necessary and impossible? Impact Assess. Proj. Apprais. 2007, 25, 233-238. [CrossRef] 
46. Olsen, S.; Galimidi, B. Catalog of Approaches to Impact Measurement: Assessing Social Impact in Private Ventures. 2008. Available online: http://socialvalueint.org/wp-content/uploads/2012/05/RIIC_Catalog Web.pdf (accessed on 2 February 2017).

47. Florman, M.; Klingler-Vidra, R.; Facada, M.J. A Critical Evaluation of Social Impact Assessment Methodologies and a Call to Measure Economic and Social Impact Holistically through the External Rate of Return Platform; LSE Enterprise Working Paper No. 1602; King's College: London, UK, 2016. Available online: http:/ / www.lse.ac.uk/businessAndConsultancy/LSEConsulting/pdf/Assessing-social-impactassessment-methods-report.pdf (accessed on 1 February 2017).

2017 by the author. Licensee MDPI, Basel, Switzerland. This article is an open access article distributed under the terms and conditions of the Creative Commons Attribution (CC BY) license (http://creativecommons.org/licenses/by/4.0/). 